\title{
Unusual Location of Glomus Tumors
}

\author{
Simona Bistazzoni*, Maria Polosa and Silvio Domenico Bellocchi \\ Department of Neurosurgery, Sant'Anna Hospital, San Fermo della Battaglia-Como, Italy
}

\begin{abstract}
Glomus tumors are rare, benign lesions that arise from glomus bodies present in the stratum reticularis throughout the body, but they are highly concentrated in the tips of the digits, especially under the nail. Although glomus tumors are benign lesions, they can cause disabling symptoms, therefore early diagnosis and treatment is important. We report an exceptional case of glomangioma of the calf.
\end{abstract}

\section{Introduction}

Glomus tumors are rare, benign, vascular tumors with a classic clinical presentation and typical symptoms of long-term pain and sensitivity to touch [1]. They arise from neuromyoarterial structures called glomus bodies. Glomus bodies are present in the stratum reticularis of the dermis throughout the body, but they are highly concentrated in the tips of the digits, especially under the nail [2]. Digital glomus tumors represent approximately $1 \%$ to $2,6 \%$ of all hand tumors and are more commonly seen in middle-aged women $[3,4]$. In contrast, extradigital cases account for $11 \%$ to $65 \%$ of all glomus tumors and are more common in older men [3-5]. They may be solitary or multiple; solitary lesions are encapsulated and most commonly subungal, while multiple tumors are unencapsulated and rarely subungal [6].

Glomus tumors are not always easy to diagnose, especially if localized extradigital and in the absence of typical symptoms. We report a case of unusual localization of multiple glomangioma.

\section{Case Report}

A 62-year-old female patient presented to the neurosurgical department with three-year history of extremily sensitive small masses on her right calf. She described an electric shock-like pain to the touch, treated conservatively with weak benefit. The pain occasionally radiated down the ankle. The masses had not subjectively grown. She had no known history of previous trauma to this area. She had history of neurinoma of left thigh surgically treated, poliomyelitis and diabetes.

On physical exam, two small round nodules approximately of 20 and $10 \mathrm{~mm}$ were palpable to the upper portion of right calf. There were significant point tenderness and dysesthesia was elicited by masses palpation. The skin surface had not a bluish or purplish discoloration. She had not motor deficit or alteration of temperature sensitivity to her right leg.

Ultrasound (US) showed the presence of two echogenic, heterogeneous, rounded soft tissue masses, well demarcated.

Magnetic Resonance Imaging scan (MRI) revealed, at the upper third of the calf at the level of the muscular belly of the lateral right twin, the presence of two expansive lesions, with polylobulates margins, one with diameters on the axial plane of $17 \times 10 \mathrm{~mm}$ and longitudinal extension of $20 \mathrm{~mm}$ and the other with diameters on the axial plane of $5 \times 6 \mathrm{~mm}$ and longitudinal extension of $10 \mathrm{~mm}$. These formations were hyperintense in T2, hypointense in T1 and demostrated diffuse homogenous enhancement on post-contrast imaging. The findings described were in the first hypothesis compatible with expansive lesions of the nerve sheats (neurinomas, schwannomas), although plurifocality and irregular morfhology were not a typical sign (Figure 1).

In the doubt of peripheral nerve lesions the patient was subjected to electromyography-neurography showed a picture of diabetic sensorymotor polineuropathy.

On $20^{\text {th }}$ March 2019, the patient underwent complete resection of the masses after pre-operative US check. A curvilinear skin incision was made at upper part of the right calf. The superficial fascia was opened, and pathologic tissue was identified. The masses were removed enbloc and sent for histological examination. The wound was closed with subcutaneous and cutaneous sutures.

Histology showed abnormal, dilated, thin walled, vascular channels lined with multiple layers of glomus cells, confirming the diagnosis of glomangioma (Figure 2).

She did not have biallelic modification of the neurofibromatosis type 1 (NF1) gene in their tumors.

The patient reported a complete and immediate resolution of the pain in her right lower limb. Symptom relief persisted at one year. No recurrence has been detected during the 11 months follow-up (Figure 2).

\section{Discussion}

Glomus tumor is very rare soft tissue tumor, typically located in the fingers, palm and sole and its most common location is the subungual area of the hand fingers [7]. Extradigital location are even rarer [8]. They have been described in almost every location, even

${ }^{\star}$ Correspondence to: Simona Bistazzoni, Department of Neurosurgery, Sant'Anna Hospital, San Fermo della Battaglia-Como, Italy, Tel: 0315859648; E-mail: simona.bistazzoni@virgilio.it

Key words: Glomus tumor, calf, extradigital location

Received: December 02, 2020; Accepted: December 15, 2020; Published: December 18, 2020 


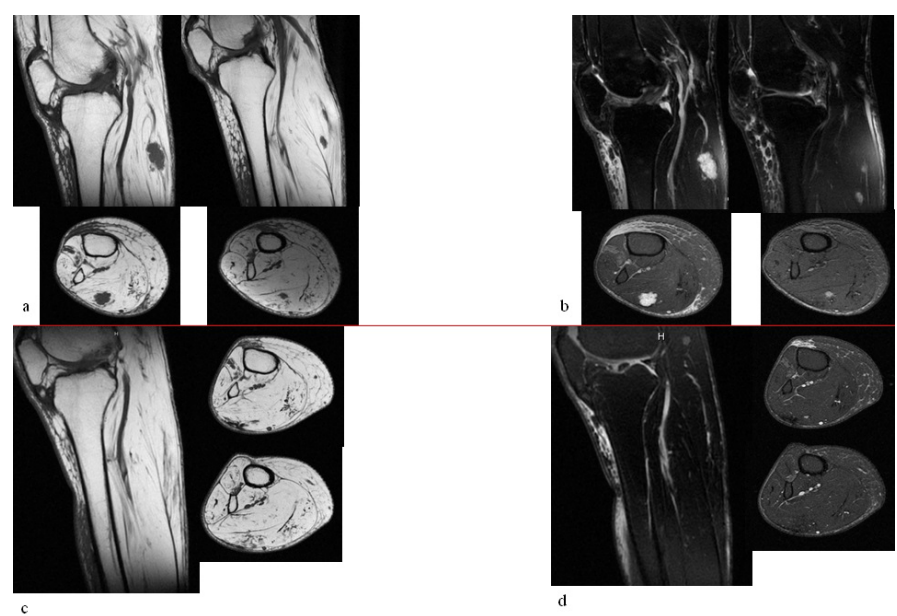

Figure 1. The lesions appear hypointense in T1 weighted sequences (a), amd hyperintense in T2 weighted sequences (b), Post-operative MRI shows no recurrence at 11 months after surgery $(c, d)$

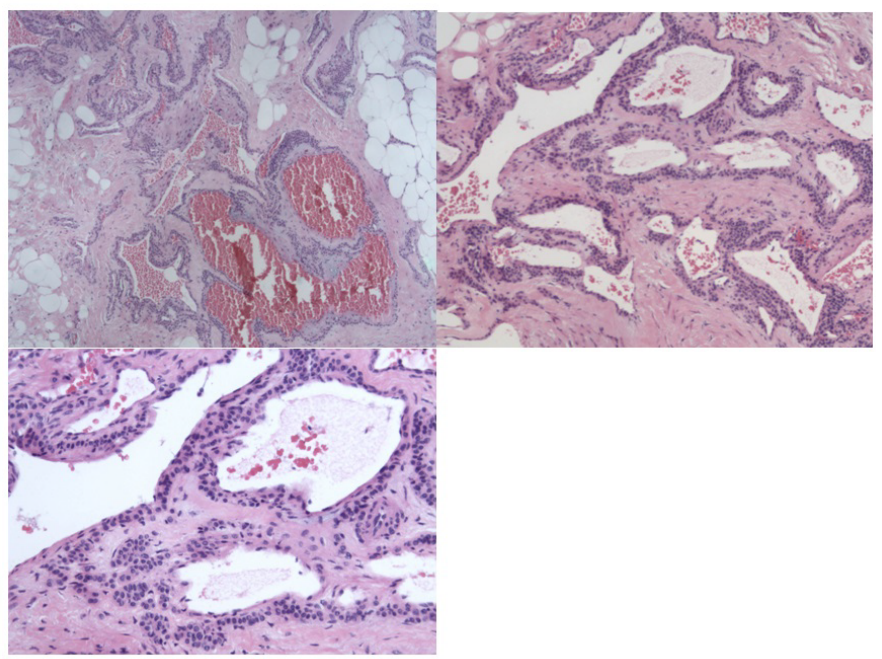

Figure 2. Histology showed abnormal, dilated, thin walled, vascular channels lined with multiple layers of glomus cells where glomus bodies do not normally occur, such as deep soft tissues, mediastinum, penis, cervix, vagina, pterygoid fossa, knee, arm, lower limb, blood vassels, nerve, bone, coccix, nasal cavity, tongue, trachea, gastrointestinal tract or viscera such as the stomach, small bowel and lung [9-14]. The intramuscular location in the calf is exceptional and only a few cases were reported in the english literature.

We only found 5 studies: 4 case reports $[15,16]$ and 1 retrospective serie [17] of certain intramuscular glomus tumor of the calf (Table 1).

Freire, et al. [15] showed a case of 16 years old male patient with a single intramuscular glomus tumor of the calf of $30 \mathrm{~mm}$ in size, with history of previous glomus tumor in the distal right leg.

Glazebrook, et al. [16] reported a case of 50 years old female patient with 4 extradigital glomus tumors of the leg (calf and ankle), 2 subcutaneous and 2 intramuscular (ranging in size from 7 to $52 \mathrm{~mm}$ ).

Saka, et al. [17] showed a case of 25 years old male patient with a single intramuscular glomus tumor of the calf of $4 \mathrm{~mm}$ in size, with history of previous trauma.

Chiang, et al. [18] reported a case of 51 years old male patient with 6 intramuscular glomus tumors of the right calf of $5 \mathrm{~mm}$ in size, with history of previous glomus tumor in the same leg.

Glazebrook, et al. 2011 [19] published a serie of 74 extradigital tumors of the extremities including 14 of thigh/calf only one intramuscular (ranging in size from 1 to $52 \mathrm{~mm}$ ). In the latter study we found some difficulties in finding information exclusively concerning calf tumors.

Other studies [4,20-27] have reported cases of glomus tumors of the leg but without specifying their deep localization, probably due to the retrospective nature of the review, some variables may not be reported consistently.

At one time, this tumor was considered to derive from the neuromyoarterial canal system called the Sucquet-Hoyer canals of the glomus body in the stratum reticularis of the dermis [28]. At present, however, it is believed that the tumor arises from pericytes, perivascular smooth muscle cell, as they differentiate into glomus cells. This also explains the occurrence of a glomus tumor at an ectopic site without pre-existing glomus bodies $[10,11,29]$.

Table 1. English Literature studies

\begin{tabular}{|c|c|c|c|c|c|c|c|c|c|c|}
\hline & Seat & $\begin{array}{c}\text { Age } \\
\text { Gender }\end{array}$ & $\begin{array}{l}\text { Solitary/ } \\
\text { Multiple }\end{array}$ & Depth & Dimension & $\begin{array}{c}\text { First } \\
\text { presentation }\end{array}$ & Imaging & Hystology & Symptoms & Recurrence \\
\hline $\begin{array}{c}\text { Chiang, et al. } \\
{[18]}\end{array}$ & calf & 51yrs Male & Multiple & 6 Intramuscular & $5 \mathrm{~mm}$ & No & MRI & GT & $\begin{array}{l}\text {-Normal skin } \\
\text {-Pain }\end{array}$ & $\begin{array}{l}\text { Not reported } \\
\text { Unknown } \\
\text { follow-up }\end{array}$ \\
\hline $\begin{array}{l}\text { Glazebrook, et } \\
\text { al. }[16]\end{array}$ & $\begin{array}{l}\text { calf/ } \\
\text { ankle }\end{array}$ & $\begin{array}{l}50 y r s \\
\text { Female }\end{array}$ & Multiple & $\begin{array}{l}2 \text { Intramuscular } \\
2 \text { Subcutaneous }\end{array}$ & $\begin{array}{l}7 \mathrm{~mm} \\
20 \mathrm{~mm} \\
24 \mathrm{~mm} \\
52 \mathrm{~mm}\end{array}$ & Yes & US+MRI & GT & $\begin{array}{l}\text {-Normal skin } \\
\text {-Pain } \\
\text {-Tender } \\
\text { swelling deep }\end{array}$ & $\begin{array}{l}\text { Not reported } \\
\text { Unknown } \\
\text { follow-up }\end{array}$ \\
\hline $\begin{array}{c}\text { Freire, et al. } \\
\quad[15]\end{array}$ & calf & $\begin{array}{l}\text { 16yrs } \\
\text { Male }\end{array}$ & Solitary & 1 Intramuscular & $30 \mathrm{~mm}$ & No & MRI & GT & $\begin{array}{l}\text {-Normal skin } \\
\text {-Pain }\end{array}$ & $\begin{array}{c}\text { Yes after } \\
9 \text { years: } 2 \\
\text { intramuscular }\end{array}$ \\
\hline Saka, et al. [17] & calf & $\begin{array}{l}25 \mathrm{yrs} \\
\text { Male }\end{array}$ & Solitary & 1 Intramuscular & $4 \mathrm{~mm}$ & Yes & MRI & GT & $\begin{array}{l}\text {-Normal skin } \\
\text {-Pain }\end{array}$ & $\begin{array}{l}\text { No recurrence } \\
\text { at } 25 \text { months }\end{array}$ \\
\hline \multirow[b]{2}{*}{$\begin{array}{l}\text { Present case } \\
\text { report }\end{array}$} & \multirow[b]{2}{*}{ calf } & \multirow[b]{2}{*}{$\begin{array}{c}62 \mathrm{yrs} \\
\text { Female }\end{array}$} & \multirow[b]{2}{*}{ Multiple } & \multirow[b]{2}{*}{2 Intramuscular } & \multirow[b]{2}{*}{$\begin{array}{l}20 \mathrm{~mm} \\
10 \mathrm{~mm}\end{array}$} & \multirow[b]{2}{*}{ Yes } & \multirow[b]{2}{*}{ US+MRI } & \multirow[b]{2}{*}{ Glomangioma } & $\begin{array}{l}\text {-Normal skin } \\
\text {-Pain }\end{array}$ & $\begin{array}{l}\text { No recurrence } \\
\text { at } 11 \text { months }\end{array}$ \\
\hline & & & & & & & & & $\begin{array}{l}\text {-Sensitivity to } \\
\text { touch } \\
\text {-Tender } \\
\text { swelling deep }\end{array}$ & \\
\hline $\begin{array}{l}\text { Glazebrook, et } \\
\text { al. [19] }\end{array}$ & 14 thigh-calf & Unknown & $\begin{array}{l}7 \text { Solitary } \\
7 \text { Multiple }\end{array}$ & $\begin{array}{c}1 \text { Intramuscular } \\
4 \text { Intermuscular } \\
9 \text { Superficial }\end{array}$ & $1-52 \mathrm{~mm}$ & Yes & Unknown & GT & $\begin{array}{c}\text {-Pain } \\
\text {-Sensitivity to } \\
\text { touch }\end{array}$ & $\begin{array}{c}\text { Yes } \\
2 \text { recurrences }\end{array}$ \\
\hline
\end{tabular}

US: ultrasound, MRI: Magnetic Resonance Imaging, GT: Glomus Tumor 
The glomus body controls blood pressure and temperature by regulating peripheral blood flow [3].

The etiology of glomus tumors is unknown, and it may be related to trauma, or inheritance. Some authors have proposed that a weakness in the structure of a glomus body could lead to reactive hypertrophy after trauma [30].

Such risk factors were not reported by our patient, Freire, et al. [15] and Chiang, et al. [18] patient, Glazebrook, et al. 2011 [19] patients. While Glazebrook et al. 2010 [16] reported a large burn to the area from a motorcycle tailpipe, and Saka, et al. [17] reported a history of previous trauma.

Glomus tumors are comprised of different proportions of glomus cells, vascular, and smooth muscle divided into classical glomus tumor, glomangioma, glomangiomyoma according to the proportion [31]. The classical glomus tumor is composed of rich blood vessels and flaky tumor cells around blood vessels [32]. Glomangioma has larger and more irregular vascular spaces coated by a few layers of glomus cells and being less well circumscribed. This type is usually seen in multiple glomus tumors [25]. Glomangiomyoma contains multiple smooth muscle cells [1]. Other variants, such as plaque type and patch type have been described as well [27].

Among these, the solid glomus tumor is the most common (75\%), followed by glomangioma (20\%) and glomangiomyoma (5\%) [10].

Only in our case the histological diagnosis was glomangioma.

Multiple case reports, a molecular genetics study, and a recent epidemiologic study all confirm that NF1 is associated with glomus tumors and that glomus tumors should be considered part of the tumor spectrum of type I neurofibromatosis [33].

Since our patient had a history of a thigh neuroma, the tumors were subjected to research of biallelic modification of the NF1 gene; the result was negative. Freire et al. [15] patient did not have any other manifestations of NF1, so he did not fulfill the criteria for NF1.

Glomus tumors can be sporadic or familiar, solitary or multiple, digital or extradigital.

Multiple glomus tumor account for $10-20 \%$ of all glomus tumors, and has a male predominance around $4: 1$, with early onset in childhood $[2,25,32,34-37]$. The tumor is most commonly diagnosed at the age of 20-40 years $[2,38,39]$.

On the basis of the cases, we have found in the literature, calf glomus tumors can be solitary or multiple.

Freire, et al. [15] and Saka, et al. [17] were in accordance with the literature regarding sex and age, Chiang et al. [18] only for the sex, while both our case and Glazebrook, et al. 2010 [16] case was female of 62 years old and 50 years old respectively.

The classic triad of symptoms of solitary glomus tumor, consisting of paroxysmal severe pain, point tenderness and cold hypersensitivity, is often absent from multiple glomus tumor [25]. When the glomus tumor is in a subcutaneous location, it causes a characteristic reddishblue discoloration of the skin [39-43]. Glomus tumors typically have a diameter of less than about $1 \mathrm{~cm}$, and present with classic triad $[6,37]$. Those located at the lower extremity are usually encountered larger than $2 \mathrm{~cm}$ [29]. Although these symptoms and requirements are relatively characteristic, many patients do not exhibit all of them [44]. As an extra-digital glomus tumor is very rare and clinical symptoms are less specific or even absent, a diagnosis is often delayed or even mistaken. $[24,25,42,45]$.

The diagnosis of glomus tumor should involve positive results on tests: Love's pin test, a cold sensitivity test, and Hildreth's test [30]. Love's pin test utilizes the head of a pin pressed against the site of the pain to identify the focal point. For Hildreth's test (ischemia test), the patient's lesion must be first stimulated to provoke severe pain. After that, a tourniquet is applied, and Love's pin test is repeated; the absence of pain from the pin after applying the tourniquet indicates a positive result for Hildreth's test. A positive result on the cold sensitivity test manifests as an increase in pain due to the cold. The mechanism for this may depend on the vasodilatation of the Sucquet-Hoyer arteriovenous channels, which dilate in response to cold to prevent excessive digit heat loss [46].

All case reports did not present discoloration of the skin probably due to the deep localization of the lesions and the main symptom was pain.

Delay in the diagnosis can lead to an aggravation of the symptoms and the development of chronic regional pain syndrome. Patients with glomus tumor may spread many years in pain and distress because of misdiagnosis [3].

In our case the delay of diagnosis ( 3 years history) was probably due to the failure of lesion growth, while in Glazebrook, et al. 2010 [16] case the pain was attributed to the presence of a large burn.

US imaging is considered as the initial and usually the most useful method for the evaluation of the glomus tumor and demostrates hypoechoic solid masses with regular borders normally located in the subcutaneous tissue. Doppler US imaging was performed for the differential diagnosis of the lesion from a vascular lesion due its dense vascular nature $[47,48]$.

As glomus tumors comprised of different proportions of different type of cells, they have different aspect on US, only little blood flow was generally visible in glomangioma, while ultrasound cannot detect blood flow in glomangiomyoma due to rare vascular or vasodilatation with trombosis. Typical glomus tumors showed single low echo with a clear boundary and visible blood flow signals [20].

US is useful to locate the lesion in the immediate pre-operative period in order to minimize the surgical approach.

MRI, especially in high resolution, represents the most sensible and specific tool distinguishing between the tumor itself and the normal tissue [24]. Glomus tumor presents as a small well-circumscribed mass that is isointense-to-slightly-hypointense on T1-weighted sequences and hyperintense on proton density or $\mathrm{T} 2$-weighted sequences with homogeneous enhancement $[49,50]$.

Glomangiomas are less well-circumscribed than glomus tumors and they have a superficial, gross and microscopic resemblance to cavernous hemangioma [51].

MRI has a sensitivity of $90 \%$ and a positive predictive value of $97 \%$. However, the specificity is only $50 \%$, and negative predictive value only $20 \%$ [52-54].

MRI is useful when the location or size of the lesion is in doubt or multifocal lesions are to be ruled out $[55,56]$ and in case of persistence of pain after surgical removal due to the presence of undiagnosed micro masses with US. 
Radiologically, a glomus tumor should also be differentiated from enchondromas, epidermal inclusion cysts, neuroma, metastasis, aneurismal bone cysts, sarcoidosis eccrine spiradenomas, leiomyomas, neuromatosis hyperplasias, multiple hemangiomas, angiomyoma, peripheral nerve sheath tumor [57,58].

The diagnosis of extradigital glomus tumors should be combined with clinical manifestations, US imaging and with MRI when necessary [20].

In our case, on the basis of the clinical features, that were not completely typical, and of the US and MRI images, we were unable to make a diagnosis, misleaded intramuscular location where glomus bodies are normally not present.

Surgical excision of glomus tumors is usually effective and curative, and the $10 \%$ of cases that precociously recur typically involve incomplete excision [50-59]; instead, recurrences occurring at the postoperative second or third year are usually caused by multiple primary tumors $[8,34]$. The recurrence rate reported varies from $1 \%$ to $18 \%$ depending on the series. Spontaneous regression is possible. Malignant degeneration is rare [24].

All cases found in the literature have been treated surgically.

Freire, et al. [15] reported a recurrence after 10 years, even Glazebrook, et al. [19] showed 2 cases of recurrence.

Small and superficial lesions may also be treated with laser ablation using argon or carbondioxide lasers [34]. In multiple cases located in the extremities, sclerotherapy using sodium tetradesyl or hypertonic saline solution is considered as an alternative [29].

\section{Conclusion}

Despite the limited data found in the literature, we can say that extradigital intramuscular glomus tumors of the calf are extremely rare and their diagnosis is not simple as they do not occur with the typical symptomatic triad, can be solitary or multiple, can be present at any age without gender prevalence. Their common characteristics are normal skin and disabling pain despite their small size, therefore early diagnosis is important. Surgery provides symptomatic relief and can be definitively curative.

Physichians in case of atypical location of painful mass, should consider glomus tumor.

\section{Conflicts of Interest}

The authors declare that they have no conflict of interest.

\section{References}

1. Jouari OE, Gallou JS, Elloudi S, Senhaji G, Rimani M, et al. (2018) A painless glomus tumor: a case report. J Med Case Rep 12: 302. [Crossref]

2. Theumann NH, Goettmann S, Le Viet D, Resnick D, Chung CB, et al. (2012) Recurrent glomus tumors of fingertips: MR imaging evaluation. Radiology 223: 143-151. [Crossref]

3. Lee SK, Song DG, Choy WS (2014) Intravascular glomus tumor of the forearm causing chronic pain and focal tenderness. Case Rep Orthop 2014: 619490. [Crossref]

4. Schiefer TK, Parker WL, Anakwenze OA, Amadio PC, Inwards CY, et al. (2006) Extradigital glomus tumors: a 20-year experience. Mayo Clin Proc 81: 1337-1344. [Crossref]

5. Saadah MA, El Beshari M, Al Heis M (2016) Intracephalic glomus tumor presenting as peripheral neuropathic pain and literature review. Int J Diagn Imaging 3: 55-62.

6. McDermott EM, Weiss AP (2006) Glomus tumor. J Hand Surg Am 31: 1397-1400.
7. Tang CY, Tipoe F, Fung B (2013) Where is the lesion? Glomus tumours of the hand. Arch Plast Surg. 40: 492-495. [Crossref]

8. Folpe AL, Fanburg-Smith JC, Miettinen M, Weiss SW (2001) Atypical and malignant glomus tumors: Analysis of 52 cases, with a proposal for the reclassification of glomus tumors. AM J Surg Pathol 25: 1-12. [Crossref]

9. Scheithauer BW, Rodriguez FJ, Spinner RJ, Dyck PJ, Salem A, et al. (2008) Glomus tumor and glomangioma of the nerve. Report of two cases. J Neurosur 108: 348-356. [Crossref]

10. Gombos Z, Zhang PJ (2008) Glomus tumor. Arch Pathol Lab Med 132: 1448-1452.

11. Heys SD, Brittenden J, Atkinson P, Eremin O (1992) Glomus tumor: an analysis of 43 patients and review of the literature. Br J Surg 79: 345-347. [Crossref]

12. Chatterjee JS, Youssef AHK, Brown RM, Nishikawa H (2005) Congenital nodular multiple glomangioma: a case report. J Clin Pathol 58: 102-103. [Crossref]

13. Fletcher CDM, Unni K, Merentens F (2002) Pathology and Genetics of Tumours of the Nervous System. Lyon, France: IARC Press. World Health Prganization of Tumours 5: 136-137.

14. Duncan L, Harverson J, DeSchryver-Kecskemeti K (1991) Glomus tumor of the coccyx: a curable cause of coccygodynia. Arch Patol Lab Med 115: 78-80. [Crossref]

15. Freire M, Rubin B, Lietman S, Sundaram M (2012) Solitary glomus tumor recurring as multiple glomus tumors. Skeletal Radiol 41: 1333-1337. [Crossref]

16. Glazebrook KN, Most MJ, Schiefer TK, Inwards CY, et al. (2010) Multiple glomus tumors of the lower leg. J Ultrasound Med 29: 667-670. [Crossref]

17. Saka G, Durkaya SM, Küçükdurmaz F, Sağlam N, Karabulut MH (2012) A Rare Cause of Calf Pain: Extradigital Glomus Tumor: Case Report. Turkiye Klinikleri J Med Sci 32: 854-858.

18. Chiang ER, Chen TH (2008) Multiple glomus tumors in gastrocnemius muscle: a case report. Arch Orthop Trauma Surg 128: 29-31. [Crossref]

19. Glazebrook KN, Laundre BJ, Schiefer TK, Inwards CY (2011) Imaging features of glomus tumors. Skeletal Radiol 40: 855-862. [Crossref]

20. Fan Z, Wu G, Ji B, Wang C, Luo S, et al. (2016) Color doppler ultrasound morphology of glomus tumors of the extremities. Springerolus 5:1319. [Crossref]

21. Bargon CA, Mohamadi A, Talaei-Khoei M, Ring DC, Mudgal CS (2019) Factors associated with requesting Magnetic Resonance Imaging during the management of glomus tumors. Arch Bone Jt Surg 7: 422-428. [Crossref]

22. Catalano O, Roldän FA, Solivetti FM, Scotto di Santolo M, Bouer M, et al. (2017) Color Doppler Sonography of Extradigital Glomus Tumors. J Ultrasound Med 36: 231238. [Crossref]

23. Bargon CA, Mohamadi A, Talaei-Khoei M, Ring DC, Mudgal CS (2019). Factors associated with requesting magnetic resonance imaging during the management of glomus tumors. Arch Bone J Surg 7: 422-428. [Crossref]

24. Sbai MA, Benzarti S, Gharbi W, Khoffi W, Maalla R (2018) Glomus tumor of the leg: a case report. Pan Afr Med J 31: 186. [Crossref]

25. Lyu YH, Gu XL, Liang ZH (2015) Multiple glomus tumor on the anteromedial side of leg. Chronic Dis Transl Med 1: 187-190. [Crossref]

26. Luis LR, Kaoru GR, Shemuel PB, Mills JL (2008) Lower extremity glomus tumors comprehensive review for surgeons. Vascular 16: 326-32. [Crossref]

27. Lee DW, Yang JH, Chang S, Won CH, Lee MW, et al. (2011) Clinical and pathological characteristics of extradigital and digital glomus tumors: a retrospective comparative study. J Eur Acad Dermatol Venereol 25: 1392-1397. [Crossref]

28. Greenspan A, Jundt G, Remagen W. Differential Diagnosis in Orthopaedic Oncology Second edition. 374 .

29. Frumuseanu B, Balanescu R, Ulici A, Golumbeanu M, Barbu M, et al. (2012) A new case of lower extremity glomus tumor. Up-to date review and case report. $J$ Med Life 5: 211-214

30. Morey VM, Garg B, Kotwal PP (2016) Glomus tumours of the hand: review of literature. J Clin Orthop Trauma 7: 286-291. [Crossref]

31. Antony FC, Cliff S, Cowley N (2003) Complete pain relief following treatment of a glomangiomyoma with the pulsed dye laser. Clin Exp Dermatol 28: 617-619. [Crossref]

32. Iliescu OA, Benea V, Georgescu SR, Rusu A, Manolache L (2008) Multiple glomus tumors. J Dematol Case Rep 2: 24-27. [Crossref] 
33. Harrison B, Sammer D (2014) Glomus Tumors and Neurofibromatosis: A Newly Recognized Association. Plast Reconstr Surg Glob Open 2: e214 [Crossref]

34. Rao AG, Indira D, Kamal J (2010) Extra digital glomangioma. Indian J Dermatol 55: 397-398. [Crossref]

35. Shin DK, Kim MS, Kim SW, Kim SH (2010) A painful glomus tumor on the pulp of the distal phalanx. J Korean Neurosurg Soc 48: 185-187. [Crossref]

36. Di Chiacchio N, Loureiro WR, Di Chiacchio NG, Bet DL (2012) Synchronous subungual glomus tumors in the same finger. An Bras Dermatol 87: 475-476. [Crossref]

37. Carroll RE, Barman AT (1972) Glomus tumors of the hand: review of the literature and report on twenty-eight cases. J Bone Jt Surg Am 54: 691-703. [Crossref]

38. Walker EA, Salesky JS, Fenton ME, Murphey MD (2011) Magnetic resonance imaging of malignant soft tissue neoplasms in the adult. Radiol Clin North Am 49: 1219-1234. [Crossref]

39. Clark ML, O'Hara C, Dobson PJ, Smith AL (2009) Glomus tumor and knee pain: a report of four cases. Knee 16: 231-234. [Crossref]

40. Deger AN, Deger H, Tayfur M, Balcioglu MG, Kadioglu E (2016) Acquired solitary glomangiomyoma on the forearm: a rare case report. J Clin Diagn Res 10: ED10-ED11. [Crossref]

41. Muneer M, Alkhafaji A, El-menyar A, Al-hetmi T, Al-basti H, et al. (2016) Intravascular extra-digital glomus tumor of the forearm. J Surg Case Rep 2016: rjw124.

42. Lee S, Le H, Munk P, Malfair D, Lee CH, et al. (2010) Glomus tumour in the forearm: a case report and review of MRI findings. JBR-BTR 93: 292-295. [Crossref]

43. George SM, Morrison IK, Farrant PB, Coburn PR (2012) Intravenous glomus tumour of the upper arm. BMJ Case Rep. 18: 2012.

44. Phillips CS, Murphy MS (2002) Vascular problems of the upper extremity: a primer for the orthopaedic surgeon. J Am Acad Orthop Surg 25: 69-71. [Crossref]

45. Hardy P, Muller GP, Got C, Lortat-Jacob A, Benoit J (1998) Glomus tumor of the fat pad. Arthroscopy 14: 325-328.

46. Srinivasan D, Rajappa S (2014) Glomus tumor of digital nerve - a case report. J Hand Microsurg 6:106-107.
47. Drapé JL, Idy-Peretti I, Goettmann S, Wolfram-Gabel R, Dion E, et al. (1995) Subungual glomus tumors: evaluation with MR imaging. Radiology 195: 507-515. [Crossref]

48. Tony G, Hauxwell S, Nair N, Harrison DA, Richards PJ (2013) Large Plaque-Like Glomangioma in a patient with multiple glomus tumours: review of imaging and histology. Clin Exp Dermatol 38: 693-700. [Crossref]

49. Tsuneyoshi M, Enjoji M (1982) Glomus tumor: a clinicopathologic and electron microscopic study. Cancer 50: 1601-1607. [Crossref]

50. Kawanami K, Matsuo T, Deie M, Izuta Y, Wakao N, et al. (2016) An extremely rare case of a glomus tumor in the popliteal fossa. J Orthop 13: 313-315. [Crossref]

51. Mitchell A, Spinner RJ, Ribeiro A, Mafra M, Mouzinho MM, et al. (2012) Glomus tumor of digital nerve: case report. J Hand Surg Am 37: 1180-1183. [Crossref]

52. Kumar R, Vu L, Madewell JE, Herzog CE, Bird JE (2017) Glomangiomatosis of the sciatic nerve: a case report and review of the literature. Skeletal Radiol 46: 807-815. [Crossref]

53. Ham KW, Yun IS, Tark KC (2013) Glomus tumors: symptom variations and magnetic imaging for diagnosis. Arch Plast Surg 40: 392-396. [Crossref]

54. Al-Qattan MM, Al-Namla A, Al-Thunayan A, Al-Subhi F, El-Shayed AQF (2005) Magnetic resonance imaging in the diagnosis of glomus tumours of the hand. $J$ Hand Surg $\mathrm{Br}$ 30: 535-540. [Crossref]

55. Matloub HS, Muoneke VN, Prevel CD, Sanger JR, Yousif NJ (1992) Glomus tumo imaging: use of MRI for location of occult lesions. J Hand Surg Am 1992; 17: 472-475. [Crossref]

56. Trehan SK, Athanasian EA, DiCarlo EF, Mintz DN, Daluiski A (2015) Characteristics of glomus tumors in the hand not diagnosed on magnetic resonance imaging. $J$ Hand Surg Am 40: 542-545. [Crossref]

57. Carvalho VO, Taneguchi K, Giraldi S, Bertogna J, Marinoni LP, et al. (2001) Congenital plaquelike glomus tumor in a child. Reis Pediatr Dermatol 18: 223-226. [Crossref]

58. Singh D, Garg RS, Vikas, Garg Y, Arora V (2016) Glomus tumor - a rarity; M.R.I. - A big help in early diagnosis. J Orthop Case Rep 6: 38-39. [Crossref]

59. Retting AC, Strickland JW (1977) Glomus tumor of the digits. J Hand Surg Am 2 261-265. [Crossref]

Copyright: (C2020 Bistazzoni S. This is an open-access article distributed under the terms of the Creative Commons Attribution License, which permits unrestricted use, distribution, and reproduction in any medium, provided the original author and source are credited. 